Pidpala Iryna. Legal factors of employment of seafarers. Journal of Education, Health and Sport. 2020;10(12):339-352. eISSN 23918306. DOI http://dx.doi.org/10.12775/JEHS.2020.10.12.033

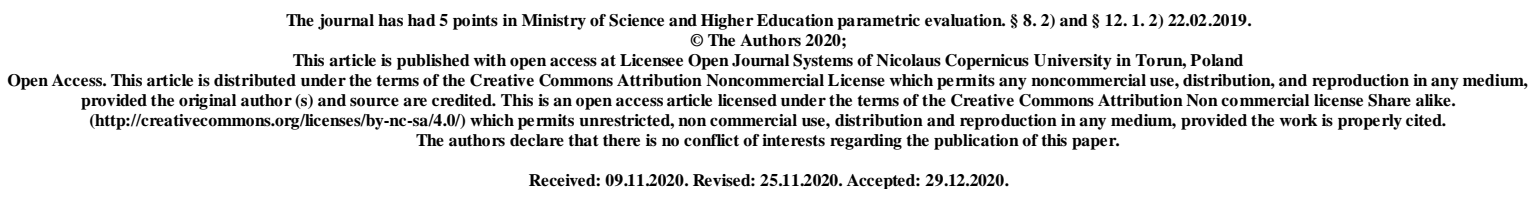

UDK 349.2

\title{
LEGAL FACTORS OF EMPLOYMENT OF SEAFARERS
}

\section{Iryna Pidpala}

\section{Medical-Natural University}

Department of General Disciplines

\begin{abstract}
The article is devoted to the study of legal regulation of the employment of sailors. Employment is an independent procedure that implies a job acceptance and includes a certain number of actions as a candidate for the post and shipowner. Installed, the specificity of marine hiring requires special conditions and regulation of labor relations, including the norms of domestic legislation and international. Depending on the position, a certain number of qualified documents that have been checking are established. Feature when taking a sailor to work Captain's coordination.
\end{abstract}

Key words: sailor; captain; labor relations; employment; employment; crewing;

\section{legislative norms.}




\title{
ПРАВОВЫЕ ФАКТОРЫ ТРУДОУСТРОЙСТВА МОРЯКОВ
}

\author{
Ирина Подпалая \\ Медико-природнический университет \\ Кафедра общих дисциплин
}

\begin{abstract}
Аннотация
Статья посвящена исследованию правового регулирования трудоустройства моряков. Трудоустройство это самостоятельная процедура, которая подразумевает принятие на работу и включает в себя определенный ряд действий как кандидатом на должность так и судовладельцем. Установлено, специфика морского найма требует особенных условий и регулирования трудовых отношений, включая нормы отечественного законодательства так и международные. В зависимости от должности устанавливается определенное количество квалифицированных документов, прошедших проверку. Особенность при приеме моряка на работу согласование капитана.
\end{abstract}

Ключевые слова: моряк; капитан; трудовые отношения; прием на работу; трудоустройство; крюинг; законодательные нормы.

Presentation of the basic material. The employment of a sailor begins with a job reception procedure. "Reception to work is a series of actions beginning to the organization to attract candidates that possess the qualities necessary to achieve the goal set by the organization." Reception to work is a necessary part of personnel management. The process of reception to work consists in comparing the requirements offered by the employer, the qualifications of the candidate. When employment of a sailor to a navigable or shipowner company, the personnel management service determines the level of competence of the sailor and the degree of its professional suitability for occupying a certain position on the vessel organization. Checking the availability of working diplomas, confirmations to them, other certificates (certificates), which confirm the level of skills of the seaman. The primitive document confirming the presence of higher marine education in the specialty "Shipwide" is a diploma of the relevant university. Next - certificates (certificates) certifying the presence of knowledge from special disciplines. Depending on a particular position, a swimming process, 
a certain number of qualifying documents are established for each caste of a ship's hierarchy [1].

The basis of legal regulation of labor sailors of Ukraine is the Code of Laws on Labor and General Norms of Labor Laws of Ukraine. But given the fact that the SUP was adopted in 1971 and despite many numerical changes and additions, in essence and laid down principles, it reflects that politically - social system that existed at that time. The Code needs a serious view. Today, projects of the Labor Code of Ukraine, which give hope that in not a very distant future, the new Labor Code will still be accepted. Nevertheless, the specificity of maritime work requires the accounting of special conditions, and, accordingly, addition to the Labor Code in the use of other normative legal acts. Since Ukraine is one of the world's largest workforce providers (seamen) for the fleet, and ranks on this 3-4 th place among all the countries of the world [2].

And at present, shipping, through objective factors, is one of the first, created and effectively uses an open labor market, turning into a global transnational shipping industry. In the world market of goods, labor and capital, the shipping industry feels significant structural changes relating to property issues, financing, insurance and acquisition of crews. Such changes are due to globalization of the world economy, in particular, the economy of the navy, the role of which grows in the global production cycle. The general structure of the navy of Ukraine adopted international global scales, when shipowners, charterers, operators and crews of vessels became representatives of different countries [3].

The structural globalization of navigation means acute competitive struggle for reducing labor costs, the use of cheap labor markets. In the world market, its segmentation is increasingly manifested. One of the segments of the world market form sailors of Ukraine. The signs of this segment are high professionalism, endurance, sociability and not a high pay. For a sufficient level of ownership of a foreign, and in front of - in English, they can work effectively in various crews [4].

In nature, the working conditions of sailors are such that international legal regulation is needed. Of particular importance in this process is the ILO, since it consolidated some general principles of employment and employment in their conventions [2].

Article 1 of the Convention No. 122 "On Employment Policy" dated July 9, 1964 (Ukraine ratified) proclaims an active policy of states aimed at promoting complete, productive and free-chosen employment of the able-bodied population in order to stimulate economic growth and development, rising living standards, satisfaction of working force and elimination of unemployment and part-time employment [5]. Convention No. 168 "On 
Promotion of Employment and Unemployment Protection" dated 12.06.1988 in Article 7 determines the means of promoting employment, including training and professional orientation [6]. Convention No. 2 "On Unemployment" of 29.10.1919 and No. 88 "On the organization of employment service" from 09.07.1948 in the second article oblige States to create free employment centers $[7,8]$.

At the same time, in maritime companies there was a false practice of ignoring international and Ukrainian norms on labor, including the issue of hiring and dismissal, payment of wages, payment of the amount of compensation for damage, payment of hospital letters, repatriation of sailors and second issues. This kind of violation is characteristic not only on vessels under the Ukrainian flag, but also on the vessels of the Ukrainian shipowners registered by them under foreign flags in offshore zones [9].

In countries, prosperous with an economic point of view, a sailor's profession. Not a prestigious, because on the shore, without separation from the family and related stresses the amount of wages above, than in seamen. The growing ran of marine officers in Great Britain and France, as well as other European countries, is known about eight years. In the prosperous Greece today, since it was in it more than ten years later, there was a crisis, which will lead to a medium reduction of employee income by 25 percent and more and willing to go to the sea under the "profitable flag" will be enough.

Thus, today, one of the defining factors that have a direct impact on the state of the sailors' labor market is the general situation on the world navy. The cheerfulness of international shipping and the growth of goods transported entails the need for new investment in shipping, which in turn visits an increase in demand for qualifying labor. The real prospects for employment by Ukrainian sailors are opened on vessels under the so-called "profitable flag". Marine administrations of the state of the "beneficial" flag do not give great importance to the standards of technical condition and the equipment of the vessel. All this opens the field of activity for firms that exploit vessels with minimal costs. They save on repairs, regulatory examinations of the underwater part of the vessel, on spare parts and other. As a result, Liberia, Panama or Cyprus are traditionally considered as the states of a "beneficial" flag, including in its registers the sea vessels tonnage millions of gross - register tone [10].

In 1950, under the "profitable" flag was registered about $10 \%$ of the world tonnage, in the late 60 's $-20 \%$, then in 1991, this figure was already $30 \%$. According to the International Federation of Transportants, in 1992. Under the "profitable" flag was registered with $80 \%$ of Hong Kong Marine Trade Fleet, 72\% - Great Britain, 57\% - Germany, 44\% - Norway, 37\% - 
South Korea [11]. Today, about 50\% of the world fleet vessels are ships under "profitable flags". But in Ukraine, the nationality of vessels are "closed", that is, the flag of Ukraine is not "convenient", this means that under the banner of Ukraine can swim a ship belonging to the legal entity of Ukraine or a citizen of Ukraine. Despite a number of difficulties associated with obtaining not "convenient" flags, vessels that swim under such flags have a number of advantages, in particular, the owners of such vessels Financial institutions are more willing to issue loans, such vehicles are protected by the Naval Forces of the country concerned. Being on a vessel under the flag of such a state, for example, the Federal Republic of Germany, you can be sure that you will receive a service for standards adopted in the European Union. In Ukraine, they are accounted for about $20 \%$, to date, this figure increases, and the number of vessels sold under "profitable" flags is also increasing.

The concept of "profitable" flag and its essence lies in the fact that a number of states: Cyprus, Panama, Costa Rica and others, adopted laws on the conditions for registration of foreign trade vessels, which allow to bypass competitors under national flags of developed states. This is achieved by simplification, and in the course of intentional understatement of legislative standards in the social and labor and taxation. The most important features of the "profitable" flag is the relative simplicity of obtaining the consent of the state of the flag for re-registration and a limited number of associated formalities; A relatively low payment of the registration fees for the implementation of legal actions on re-registration of the vessel under a profitable flag and introduction to a profitable register, very low tax rates or the lack of taxpayers paid by shipowners, the absence of a lower grace in paying members of the crew [12].

The activities of the International Federation of Transportants to combat "profitable" flags sometimes reaches the opposite result than which it is struggling. On-time, under the "profitable" flags of Liberia and Panama there are more than 7420 vessels with a total gross capacity of about 112 million gross-register tons. For comparison: the gross capacity of the fleet floating under the banners of ten leading states of the world is 230 million grossregistration tone. If Liberia and Panama will refuse the practice of a "profitable" flag, this will lead to a loss of 130 thousand jobs (with an average number of crews in 20 people) and the transition to a personnel reserve of about 180 thousand people. Therefore, the policy of MFT to combat "profitable" flags is not supported by seats themselves. In addition, at the MFT seminar on the topic: "Advantageous" flags on January 19, 2003. It was noted that the MFT policy is very cruel. "Not all" beneficial "flags are the same, - noted the representative of the Italian Association of Sunfitarma shipowners, - the conditions for some of them are very 
good, even better than the vessels under the national flag." The International Federation of Transportants itself is also low enough to assess the results of its 50-year-old fight against "profitable" flags. Online, on the 39th Congress of the IFT, which took another November 5, 1998 in New Delhi, it was noted that "50 years after the campaign against the" beneficial "flags on the congress in Oslo, such registers continue to be distributed. Jobs for sailors in native countries of the shipowner and the decline of bona fide navigation under the national flag " [10].

In the international labor market of sailors, the most common form of mediation is, this is a so-called Krywing. The essence of the company's activity - the intermediary is to established contact, on one side, with wanting to work as a sailor, and from the second - with a shipowner who needs to stimulate the crews of ships. Firm - the intermediary for the services provided receives a predefined reward from its client. As well as obviously, this is an absolute amount or fixed percentage from the basic salary of the sailor with the addition of the amount incurred by the company - an intermediary for financial expenses for employment.

A more complicated form of mediation is Kryuing - Management. Its essence lies in the fact that the shipowner fully translates to the firm - an intermediary responsibility for solving all issues related to the completion and control of the vessel crew. In this case, the shipowner pays a copy agent a monthly amount due to which the costs of wages are reimbursed and other expenses. At the expense of the shipowner, organizational expenses for the completion of the crew, its delivery on board the vessel, exchange by the Marine Administration of the State of the flag of the granted diplomas and qualification certificates, the cost of insurance of crew members, payment of nutrition on the vessel, payment of working clothes and means of individual occupational safety and other. In this case, the Crewing agency is interested in minimizing various costs associated with retention of the crew. This, in turn, is displayed at the wage level, which is proposed and equal to living standards during swimming. Therefore, the sailor signing a contract must check that all provisions of future work were indicated: the duration of hiring, paying, compensation and so on. Since realities show that sailors also agree in virtually any conditions contained in the document. They put their signature under contracts, which do not say about insurance, compensation in the event of injuries, illness or even death aboard the vessel. A vivid example is the contracts of Laskaridis Shipping, which even did not even discuss specific amounts of compensation. The contract noted only that "the shipowner must insure members of the crew in insurance companies at its discretion, in case of death or disability due to accidents during their duties on board a ship under this contract." Particular attention should 
be paid to the phrase "at his discretion," which clearly does not provide material obligations to the seaman and his family. Similar contracts that do not give Ukrainian sailors are any social guarantees - about $50 \%$. The percentage is significant in order for the state to pay attention to violations of the social rights of Ukrainian sailors, and reacted at the legislative level. After all, there is still a normative document in the country that it would be foreseen that when Pai maiden, Crewing must demand a foreign shipowner guarantees of minimum wage, registration of medical and pension insurance, compensation in case of injury or death. As an example for Ukraine, even in the Philippines, where the Law established a typical labor contract of the seaman, which includes mandatory items on social protection of sailors when arranging for foreign vessels. In Ukraine, at the level of the Ministry of Labor, it would be necessary to oblige the hiring agencies to adhere to minimal standards in contracts. The fact that many Ukrainian sailors fall into slave conditions when their rights are violated, this is a consequence of not only their personal inattention, or insidious conspiracy of Kryuing and shipowners, but also inadequate legal regulation and state control in the issues of employment of seamen for foreign vessels [2].

The shipowner or his agent does not lose the rights of the employer, despite the fact that an employment contract is concluded between the Crewing Company and the sailor. Crewing companies are engaged in both the formation of full national crews and the direction of sailors individually in mixed crews (MIXED CREW, International Crew).

Practice that originated in Asia when sailors pay their agents or a fixed amount or percentage of earnings, not only did not capture themselves, but also spread to Europe. The first companies of this kind appeared in Ukraine in the mid-1990s. They are tens of them now. Therefore, it is not surprising that the International Labor Organization has repeatedly returned to the issues of hiring and employment of sailors, as well as to regulate the problem of their unemployment [13].

In the first session of the International Labor Conference, held in Washington in 1919, first considered the issue of unemployment at the international level and adopted the Convention No. 2 "On Unemployment", which came into force on July 14, 1921. As of December 31, 2002, ratified 55 states and Ukraine is a member. Article 2 of the Convention for each state is obliged to establish a system of free state employment centers [7]. Recommendations No. 1 "On Unemployment" adopted at the same session of the conference, it is envisaged that each member of the Organization shall take measures to prohibit the establishment of employment centers who pay or carry out their activities in order to profit. At the same time, if such centers have already existed, it is recommended to make all existing 
measures for their fastest elimination [14]. According to this, there are a lot of crew receiving agencies in the crane, but the state's participation in this process is limited to the license. Therefore, the conditions of hiring of Ukrainian sailors do not meet the norms of international law. Agencies are deducted from salary sailors the amount that is almost $10 \%$ of the salary in the contract. Some agencies in addition to the sailor a written commitment not to contact the IFT [15].

Also, the Convention No. 88 "On the organization of employment service," which came into force on August 10, 1950, established basic principles that employment services should be guided, and Recommendation No. 83 "On the organization of employment service" of 09.07.1948 contains detailed Indication of relatively measures to provide employment services. The scope of these two international legal documents extends to all employment services, including those who are employed by sailors $[8,16]$. This problem is devoted to a number of recommendations adopted by the General Conference of the ILO, including recommendation No. 107 "On the hiring of sailors to the vessels registered in a foreign state" of 13.05.1958, Recommendation No. 139 "Regarding Employment Problems related With technical changes on board ships "dated 29.10.1970, Recommendation No. 154" Regarding the continuity of employment of sailors "from 28.10.1976 [2].

Instentance No. 139 assumes that with the hired sailors to shipping should be taken into account existing labor plans and forecasts contained in them, and p.6 follows that labor mobility should be facilitated by an effective employment service and if employment Sailors are engaged in specialized employment agencies, these institutions are responsible for employment at enterprises on the shore, such employment should facilitate close cooperation between these institutions and the National Employment Service [17].

Convention No. 9 "On the Employment of Sailors" in 1920, adopted on the Second (Marine) session of the International Labor Conference (Genoa, 1920) and entered on November 23, 1921. As of December 31, 2001, it ratified 39 states (Ukraine is not a participant in the Convention). The Convention contains the same principles that are enshrined in the Convention No. 2 "On Unemployment" and in the Convention No. 145 (1976) "On the continuity of employment of sailors", which entered May 3, 1979, ratified by 17 states, (Ukraine - Not a participant) in Article 3 contains a significant rule that measures that are aimed at regulating employment may include the creation and maintenance of registers or lists of qualified sailors by categories. Such activities for compiling full and available lists (electronic databases) will provide more full employment and increase the realization of the right of seamen to receive evacencies that are offered. Therefore, these 
provisions of the Convention shall be taken into account and by Ukrainian hiring agencies, despite the lack of ratification by Ukraine of this Convention [18].

In this regard, the recommendation No. 154 "On Continuous Employment Employment" complements the norm of the above-mentioned Convention by paragraphs 2 and 3, which provides for the possibility of guaranteeing continuous and regular employment with all qualified sailors, but it is necessary to accept the system of distribution of work that must be stored behind the seamen. The right to choose a vessel that he will be hired, and the right of the shipowner to choose a sailor, which he plans to hire. In our country, sailors are not given to choose from most vacant places on departure vehicles and shipowners at the same time are not fully equipped with information on qualification and able-bodied sailors, which completely excludes taking into account these provisions in Ukraine [19].

On a change in the above-mentioned conventions on February 23, 2006, the 94th conference of ILO was adopted by the Convention "On Labor in Maritime Shipping" (MLC), while united and reviewed about 36 "Marine Conventions" ILO. This Convention regulates the issues of working conditions and everyday seamen and their social protection, fixes the rights of seamen for decent working conditions and helps to create conditions for fair competition between shipowners and involves application in the global scale. Consequently, this MLC 2006 Convention has replaced by virtually all existing conventions and recommendations that have been adopted earlier ILO since 1920. It covered the entire spectrum of social and labor relations inherent in trade navigation, established requirements for age and health of the sailor, to professional sailor training, his qualifications, to the system of hiring and employment, to the main conditions of employment, and conditions of residential premises, and conditions. To relax on board a ship, as well as to social security [20].

Approximately every fifth vessel, as the global practice of manning of seaweed crews has a crew consisting of citizens of different nationalities. This is due to the first, with the need to manage vessels by highly skilled specialists, having recognized "working" diplomas, and secondly, a significant cheaper labor force, especially sailors and motors [21].

The main issue in employment is the requirements for the qualifications of crews of vessels, the question of establishing these requirements raised the issue, at the $1 \mathrm{st}$ International Maritime Organization (Washington, 1899). And despite the fact that practically not one issue of the conference was not established by a special international treaty, they still received general recognition. 
According to this, the General Conference of the International Labor Organization convened in Geneva by the Administrative Council of the International Labor Office on October 6, 1936, decided to adopt a number of proposals on the establishment of every sea state of minimum qualifications required by captains, witches of assistants, whakers of mechanics aboard ships. On the basis of this Article 3 of the Convention "On the minimum qualification of the captain and other persons of the commander of trade vessels, it provides that:" No one can be admitted or involved in ignition of captains, a vaken assistant, a senior mechanics or a watch mechanic on a vessel on which. The provisions of this Convention are distributed, without a certificate of qualification, which certifies its ability to occupy this position, which is issued or approved by the relevant authority of the territory in which the registered ship."

The acquisition of crews by qualified specialists a lot depends on the role of the captain of the vessel as a representative of the employer and in some cases - a person who signs an employment contract with a worker. In the past, when the captain was often a shipowner, he himself picked a crew on a special maritime exchange and in a port city, where all those who want to watch work on sea vessels were going to work. As a result, when the delimitation between shipowners and captain occurred, the shipowner gradually took over his captain of his election from the applicants to the crew. At the same time, the current legislation The right of actual admission to work is given too a wide range of subjects. Since the need for a sailor's reception may arise during the flight when the captain of the vessel is often the only representative of the employer on the vessel, then in the labor relations of members of the crews of maritime vessels The right to actual admission should be granted, including the captain of the vessel [2].

Consequently, in accordance with claim 1, Article 66 of KTMU none of the persons of the ship crew can not be appointed to the vessel without the consent of the captain.

At the same time, the procedure for accepting the work of the ship's crew, their rights and obligations, working conditions for vessel and remuneration, as well as social services in the sea and in the port, as well as the procedure and grounds for their release are regulated by the legislation of Ukraine, this Code, Statutes of service on marine and fishing vessels, general and sectoral tariffs, collective and labor contracts (contracts) notes claim 1 of Article 54 of KTMU [20].

By the management of the vessel, the lawfulness of the captain is also distributed to the sphere of labor relations with members of the crews. The vessel is not a legal entity, the more that the captain of the vessel has a number of labor powers in relation to the 
organization of labor and recreation of crew members, there is the right to identify apal and emergency work and other. At the same time, the captain is guided by the KPPU norms, "Regulations on working hours and recreation time of the floating composition of marine and river transport of Ukraine", approved by the draft order of the Ministry of Infrastructure of Ukraine dated November 03, 11, wherein P.2.3. Sets the 8th time-working on the vessel, although a specific schedule of VACT is being developed and approved by the shipowner or by its caption (item.2.9. This provision) [21].

Shipowner agrees with the captain of destination for a vessel of any member of the crew (item 1 of Article 66 of KTMU). The uniqueness of the situation in this case concludes that labor relations between the shipowner - the employer (including the employer of the captain, which the last accountable) and a specific worker - a member of the crew arise on the basis of two legal facts: 1) the conclusion of an employment contract that is issued by the order of the shipowner. about the appointment of a person to the vessel; 2) granting the captain of his consent to accept this worker on the vessel. In other words, the captain has a kind of veto right in terms of destination for a vessel of specific individuals. It is important that when receiving a vessel not applicable norms of the CPPP, regarding the test period, as one captain will not accept a specialist to the vessel and will not allow him to an independent vakot, if not sure that he will handle work, as it is conforming to the safety of people, vessels, cargo and the environment lies in the captain, as well as on a particular specialty, which independently performs a specific function on the vessel [1].

When employment, the captain of the captain of the vessel regarding the adoption of a crew of a person who sent a shipowner to the ship must be substantiated. Such a refusal with the appropriate justification is made in writing and transmitted by the shipowner and the person who is denied to work [20]. With the illegal failure of the sailor in reception to work, he has the right to appeal such a refusal in accordance with the general norms of labor legislation, and on the basis of special conventional norms. For example, in accordance with Article 2 of the Convention "On Minimum Rules on Trade Movements" of 29.11.1976 No. 147 (entered on November 28, 1981, ratified 42 states, including Ukraine), States are undertaken to ensure the availability of appropriate procedures, subject to general supervision by the competent authority after trilateral consultations between this authority and representative organizations of shipowners and seamen, where it is envisaged, considering any complaint that is submitted in connection with hiring and, if possible, at the time of hiring. On his territory of sailors, which is his citizens, on vessels registered in a foreign state, and that such a complaint, as well as any other complaint, submitted in connection with hiring 
and, if possible, at the time of hiring on his. The territories of foreign seamen on vessels registered in a foreign state was immediately proved by its competent authority to the attention of the competent authority of the country in which the vessel is registered, and the copy was sent General Director of the International Labor Office [22].

Unfortunately, not always the complaints of sailors lead precisely to such results they try to achieve. For example, in the Philippines, the seamen strikes are a reason for acceptance of administrative measures, as well as for automatic removal of employment permits. In addition, there is a threat to get into a "blacklist", which will be mentioned for the seaman to remove its data from the catalogs of hiring agencies, and, as a result, make employment impossible [1]. The preparation of such lists contradicts Mr. P. 2 of Article $4 \S \S 4$ of the Convention No. 179 "On Hiring and Employment of Sailors" (1996), according to which the state is obliged to prohibit hiring and employment services to use such means, measures or lists, who intend to prevent or keep sailors from receiving work [23]. In addition, according to Article 3 of the Convention "On Minimum Rules for Trading Markets", 1976, the state ratified by it shall, as far as possible, pay attention to their citizens to possible problems in connection with the hiring of a vessel registered in. The state that has not ratified this Convention until it ensures that the norms equivalent to the norms established in this Convention shall apply [22].

Conclusion. In connection with the above, it is important to emphasize the special role of captain in handling the ship's crew, as the head of the operational level of management within the company of the shipowner in the employment of sailors. Based on analyzed norms, we can conclude that our country is not a member of most of the conventions under consideration, and this in turn generates disadvantages and gaps in legislation, although Ukraine and adheres to the fundamental principles of the Marine Conventions of the ILO. In this case, Ukrainian labor legislation, unfortunately, does not contain special norms, regulatory employment of sailors.

\section{References:}

1. Butsenko Serhii Valeriiovych. Orhanizatsiino-pravovi zasady ukomplektuvannia kerivnoho skladu sudnovykh ekipazhiv v Ukraini: dys,kand. yuryd. nauk: 12.00.07 / Kharkivskyi natsionalnyi un-t vnutrishnikh sprav, - X., 2006.

2. Hutsuliak V.N. Morskoe pravo: Ucheb, posobye. - M.: RosKonsult, 2000.-S. 133. 
3. Volkova O.V. Rynok pratsi /O.V. Volkova.; navchalnyi posibnyk. - K.: Tsentr navchalnoi literatury, 2007 - 624s.

4. Libanova E. Liudyna na rynku pratsi / E. Libanova// Uriadovyi kurier. - 2004, № 74.-S.7.

5. Konventsiia pro polityku v haluzi zainiatosti N 122 (ukr/ros) Mizhnarodna orhanizatsiia pratsi; Konventsiia, Mizhnarodnyi dokument vid 09.07.1964 № 122»: URL: http: //zakon .rada.gov.ua

6. Konventsiia pro spryiannia zainiatosti ta zakhyst vid bezrobittia N 168 (ukr/ros)Mizhnarodna orhanizatsiia pratsi; Konventsiia, Mizhnarodnyi dokument vid 21.06.1988 № 168»: URL: http: //zakon.rada.gov.ua

7. Konventsiia MOP N 2 pro bezrobittia 1919 roku Mizhnarodna orhanizatsiia pratsi; Konventsiia, Mizhnarodnyi dokument vid 29.10.1919 № 2»: URL: http: //zakon.rada.gov.ua

8. Konventsiia pro orhanizatsiiu sluzhby zainiatosti N 88 Mizhnarodna orhanizatsiia pratsi; Konventsiia, Mizhnarodnyi dokument vid 09.07.1948 L«88»: URL: http: //zakon.rada.gov.ua

9. Kokyn A.S. Trudovыe konflyktы na sudakh «udobnoho» y otechestvennoho flahov. Pozytsyy pravytelstva, sudovladeltsev, moriakov.M.: Voltere Kluver, 2008. - 424 s.

10. Efymov S.L., Hutsuliak B.H., Kontalev V.A. Kak poluchyt rabotu na sudne. M, 2002.S.132

11. Kampanyia protyv deshevыkh flahov: polveka borbы// Morskoi biulleten MFT. 1997h. № 11 s.3

12. V. Lebedev, A. Nytsevych «Chto takoe «udobnыi» flah» Mezhdunarodnыi zhurnal «Sudokhodstvo», №9, 2005: URL: http:// transportinform.com/shipping/47-flag.html

13. Hutsuliak V.N. Pravovыe uslovyia naima y rabotы moriakov na sudakh pod «udobnыm flahom». Novorossyisk, 1997h. s.12

14. Rekomendatsiia pro bezrobittia N I Mizhnarodna orhanizatsiia pratsi; Rekomendatsii, Mizhnarodnyi dokument vid 29.10.1919 № 1: URL:http: //zakon.rada.gov.ua

15. Voprosы bezrobotytsy // Morskoi biulleten MFT 1998h. №: 12.S.31

16. Rekomendatsiia shchodo orhanizatsii sluzhby zainiatosti N 83 Mizhnarodna orhanizatsiia pratsi; Rekomendatsii, Mizhnarodnyi dokument vid 09.07.1948 № 83: URL: http://zakon.rada.gov.ua 
17. Rekomendatsiia shchodo problem zainiatosti, pov"iazanykh z tekhnichnymy zminamy na bortu suden N 139 Mizhnarodna orhanizatsiia pratsi; Rekomendatsii, Mizhnarodnyi dokument vid 29.10.1970: URL: http: //zakon.rada.gov.ua

18. Konventsiia pro bezperervnist zainiatosti moriakiv N 145 (ukr/ros) Mizhnarodna orhanizatsiia pratsi; Konventsiia, Mizhnarodnyi dokument № 145: URL: //zakon.rada.gov.ua

19. Rekomendatsiia shchodo bezperervnosti zainiatosti moriakiv N 154 Mizhnarodna orhanizatsiia pratsi; Rekomendatsii, Mizhnarodnyi dokument vid 28.10.1976r.№ 154: URL: http://zakon.rada.gov.ua

20. Ivanova A.V. Pravovyi analiz konventsii pro pratsiu u morskomu sudnoplavstvi 2006 roku ta natsionalnoho zakonodavstva $\mathrm{z}$ pytan pratsevlashtuvannia moriakiv: URL: www.eastwave.com.ua

21. Kodeks torhovelnoho moreplavstva Ukrainy: za stanom na 1 hrudnia 2020r. //Ofitsiinyi sait Verkhovnoi rady Ukrainy. URL: http: //zakon.rada.gov.ua

22. Polozhennia pro robochyi chas ta chas vidpochynku plavaiuchoho skladu morskoho i richkovoho transportu Ukrainy URL: http: //zakon.rada.gov.ua

23. Konventsiia pro naim ta pratsevlashtuvannia moriakiv N 179 (ukr/ros) Mizhnarodna orhanizatsiia pratsi; Konventsiia, Mizhnarodnyi dokument vid 22.10.1996 № 179: URL: http: //zakon.rada.gov.ua 